\title{
PRODUKSI DAN KUALITAS RUMPUT GAJAH KATE (Pennisetum purpureum cv. Mott) YANG DITANAM DALAM PERTANAMAN CAMPURAN RUMPUT DAN LEGUM PADA PEMOTONGAN PERTAMA
}

\author{
Kaca, I N., I G. Sutapa, L. Suariani, Y. Tonga, N.M. Yudiastari, N.K.E. Suwitari \\ Jurusan Peternakan Fakultas Pertanian Universitas Warmadewa
}

\begin{abstract}
ABSTRAK
Salah satu faktor yang memegang peranan penting dalam meningkatkan produksi ternak ruminansia adalah tersedianya hijauan makanan ternak yang berkualitas sepanjang tahun. Hijauan makanan ternak yang berkualitas terutama terdiri dari rumput rumputan sebagai sumber energi dan leguminosa sebagai sumber protein. Di Indonesia, khususnya di Bali, petani ternak masih banyak memanfaatkan rumput lapangan sebagai pakan ternaknya, karena lahan yang khusus dipergunakan untuk menanam rumput tidaklah memadai. Oleh karena itu perlu dilakukan pertanaman campuran rumput dengan legume. Untuk menghasilkan produksi yang optimum maka perlu dilakukan pemupukan. Pemupukan yang dapat dilakukan oleh petani tanpa mengeluarkan biaya tambahan adalah pemberian pupuk organik kompos dan biourine. Penelitian ini telah dilaksanakan dari bulan Nopember 2015 sampai dengan Pebruari 2016. Rancangan yang digunakan adalah Rancangan Acak Kelompok pola faktorial 3x2, dengan 3 faktor jenis tanaman: Pennisetum purpureum cv. Mott tanpa legume (Rt); ditanam bersama sentro (Rs) dan ditanam bersama dengan kalopo (Rk): dan 2 jenis pupuk yang digunakan adalah pupuk kompos (K) dan pupuk biourine (B). Masing- masing kombinasi perlakuan diulang sebanyak tiga kali. Hasil percobaan menunjukkan hasil yang berbeda sangat nyata untuk parameter produksi total hijauan segar dan kering, jumlah anakan dan jumlah daun Pennisetum purpureum cv. Mott serta komposisi botani pemotongan pertama sedangkan untuk tinggi tanaman Pennisetum purpureum cv. Mott menunjukkan hasil yang berbeda tidak nyata Pengaruh yang nyata juga diberikan jenis tanaman terhadap kandungan protein Pennisetum purpureum cv. Mott, namun tidak berpengaruh nyata untuk kandungan serat kasar Pennisetum purpureum cv. Mott. Dapat disimpulkan bahwa pertanaman campuran Pennisetum purpureum cv. Mott dengan leguminosa mampu meningkatkan produksi dan kualitas hijauan.
\end{abstract}

\section{Kata kunci: rumput gajah kate, leguminosa, produksi, kualitas hijauan}

\section{PENDAHULUAN}

Ketersediaan pakank hususnya pakan hijauan masih merupakan kendala yang dihadapi oleh para peternak khususnya pada musim kemarau. Pemanfaatan lahan-lahan yang kurang subur untuk tanaman pakan menjadi sangat penting karena belum adalahan khusus untuk tanaman makanan ternak. Lahan kosong yang luasnya ribuan hektar di Indonesia merupakan lahan yang sangat potensia lapabila dikelola dengan baik. Tanaman pakan merupakan faktor penting untuk pertumbuhan dan peningkatan produktivitas ternak ruminansia, karena sebagian besar pakan ternak ruminansia berasal dari tanaman pakan ternak (rumput dan leguminosa). Leguminosa merupakan hijauan pakan berkualitas tinggi dan andalan daerah tropik sebagai sumber nitrogen tanah (Anon,1999). Padausaha ternak ruminansia komposisi hijauan dalam ransum dapat mencapai $90 \%$. Biaya produksi hijauan yang murah akan menjamin keberhasilan usaha. Namun usaha menurunkan biaya produksi mengalami beberapa kendala, diantaranya adalah keterbatasan lahan dan biaya pemupukan.

Pola tanam tumpang sari rumput dan leguminosa merupakan salah satu cara untuk meningkatkan produksi hijauan pakan sekaligus menurunkan pemupukan nitrogen. Pola tanam tumpang sari memerlukan pengaturan penanaman yang tepat, baik jenis legume maupun jenis rumput yang ditanam. Rumput Gajah Kate (Pennisetum purpureum cv. Mott) adalah salah satu jenis rumput gajah yang baru dikembangkan sekarang ini. Ukurannya yang lebih kecil dari rumput gajah, membuatnya juga sering disebut rumput Pennisetum purpureum cv. Mott. Rumput ini dapat tumbuh pada berbagai macam tanah, sampai liat alkalis, dan sangat responsif terhadap pemupukan.

Kekurangan secara umum dari rumput gajah kate adalah cepat menua sehingga kandungan nutrisi cepat menurun dan cepat menghabiskan unsure hara yang terdapat di dalam tanah. Oleh karena itu untuk mengatasi kekurangan dari rumput gajah kate, makadianjurkan dilakukan penanaman 
campuran dengan legum. Penanaman campuran antara rumput dengan legum merupakan salah satu upaya untuk meningkatkan produksi, mutu hijauan dan memperbaiki kesuburan tanah (Chullank, 2012).

Leguminosa adalah jenis tumbuhan yang termasuk keluarga kacang-kacangan atau polong-polongan yang sangat baik digunakan sebagai pakan ternak karena kandungan proteinnya tinggi. Hijauan leguminosa, baik herba maupun pohon adalah hijauan yang mempunyai nilai gizi lebih tinggi dibandingkan dengan rumput. Kandungan protein kasarnya tinggi,sebagai sumber vitamin dan mengandung mineral yang lebih banyak dibandingkan rumput.

Banyak hijauan pakan yang potensial guna menunjang kebutuhan dalam penyediaan hijauan pakan salah satunya adalah tanaman leguminosa dari jenis centrocema. Centrocema pubescens merupakan tanaman yang tahan keadaan kering, dan dapat hidup dibawah naungan serta lahan yang tergenang air (Ibrahim, 1995). Lebih lanjut Reksohadiprodjo (1994) menyatakan bahwa Centrocema pubescens dapat ditanam secara campuran dengan rumput dan memperlihatkan pertumbuhan yang baik adalah dengan jenis rumput Panicum maximum, Melinis minutifloras erta Cynodon plectostachyon.

Salah satu tanaman cover crop dan bias dijadikan pakan ternak yang sering digunakan di lahan perkebunan/kehutanan adalah Calopogonium, tanaman ini sudah lama digunakan karena dapat menekan pertumbuhan gulma dan dapat meningkatkan kesuburan tanah. Calopogonium mucunoides berasal dari Amerika selatan yang bersifat perennial, merambat serta membelit. Telah ditanam secara luas di daerah-daerah tropic lainnya sebagai tanaman pencegah erosi, penutup tanah dan pengendali gulma serta tanaman sela. Legum ini sangat disukai oleh ternak dan dapat berproduksi dengan baik pada tanah masam dan agak kering.

Penanaman hijauan pakan ternak pada lahan yang subur menghasilkan produktivitas pakan yang lebih baik jika dibandingkan dengan lahan kritis atau kurang subur. Keberhasilan pertumbuhan hijauan pakan membutuhkan dukungan lingkungan fisik tanah dan iklim yang ideal (Sumarsono dkk, 2005). Tanah yang subur diperlukan dalam proses pertumbuhan dan perkembangan hijauan karena hijauan merupakan pakan dasar ternak ruminansia. Pemupukan merupakan salah satu cara intensifikasi pertanian yang perlu dilakukan meningkatkan hasil dan kualitas rumput dan legume pada penanaman campuran. Selain itu pemupukan juga merupakan usaha untuk memperoleh pertumbuhan dan produksi rumput gajah dan legum (sentro dan calopo) yang baik, apabila diberikan dengan dosis dan waktu yang tepat.
Pemupukan dengan pemberian kompos juga mempunyai maksud mencapai kondisi dimana tanah memungkinkan tanaman tumbuh dengan sebaikbaiknya. Keadaan tanah yang baik berarti pula, bahwa tanaman dapat dengan mudah menyerap makanan melalui akarnya yang kuat, dibanding dengan jika pertumbuhannya kurang baik maka pemberian kompos dalam pemupukan dengan sendirinya akan memberikan hasil yang lebih baik. Penggunaan kompos sebagai sumber nutrisi tanaman merupakan salah satu program bebas bahan kimia, walaupun kompos tergolong miskin unsur hara dibandingkan dengan pupuk kimia.

Berdasarkan uraian diatas, maka perlu dilakukan penelitian untuk mengetahui bagaimana pertumbuhan tanaman tumpang sari rumput dan leguminosa yang diberi pupuk kompos dan bio-urine.

\section{METODE PENELITIAN}

\section{RancanganPercobaan}

Percobaan lapanga nini dilakukan dengan menggunakan Rancangan Acak Kelompok (RAK) Pola Faktorial 3x2 dimana 3 perlakuan jenis tanaman (Faktor A) dan 2 perlakuan pupuk (Faktor B). Faktor A (Jenis Tanaman) yaitu Rt (Rumput Pennisetum purpureum cv. Mott), Rs (Rumput Pennisetum purpureum cv. Mott + Sentro) dan Rk (Rumput Pennisetum purpureum cv. Mott + Kalopo). Sedangkan Faktor B (Jenis Pupuk) yaitu B (Biourine) dan K (Kompos).

\section{Lokasi dan Waktu Penelitian}

Percobaan ini dilakukan di Stasiun Percobaan Fakultas Pertanian, Universitas Warmadewa Denpasar. Penelitian dilaksanakan mulai tanggal 24 November 2015 sampai dengan tanggal 3 Pebruari 2016 selama 70 hari.

\section{Pelaksanaan Percobaan \\ 1. Persiapan petak dan penanaman}

Tanah yang sudah diolah kemudian dibuat blok dan petakan sesuai dengan kebutuhan penelitian. Setelah petakan sudah siap, dilakukan pengacakan pada setiap blok. Sebelum penanaman terlebih dahulu dilakukan pemilihan bibit tanaman dengan ukuran yang sama pada setiap bloknya. Bibit yang sudah dipilih kemudian ditanam pada petak yang sudah disiapkan dengan kedalaman satu ruas dalam tanah untuk rumput gajah kate (Pennisetum purpureum cv. Mott), sedangkan legum (sentro dan kalopo) ditanam sesuai dengan ukuran yang telah ditentukan. Luas petak yang digunakan adalah panjang 1,2 $\mathrm{m}$ dan lebar 1,6 m. Dalam satu petak ditanam 3 jenis tanaman yaitu rumput gajah kate (Pennisetum purpureum 
cv. Mott), kalopo dan sentro dengan jarak tanaman antara rumput dengan rumput $70 \mathrm{~cm}$, rumput dengan legume (sentro dan kalopo) $40 \mathrm{~cm}$. Setelah rumput dan legum ditanam dilakukan penyiraman secara keseluruhan.

\section{Pemberian pupuk}

Pupuk yang diberikan dalam penelitian ini adalah pupuk kompos dan biourine. Jumlah pupuk kompos yang diberikan adalah 3 ton/ha dan pemberian setiap petak adalah $576 \mathrm{~g} /$ petak, sedangkan jumlah pupuk biourine yang digunakan $450 \mathrm{l} / \mathrm{ha}$ dan pemberian setiap petaknya adalah $86,4 \mathrm{ml} /$ petak. Perlakuan dilakukan dua kali dengan dibagi dua dosis pupuk yang diberikan. Pemupukan pertama dilakukan 1minggu sebelum penanaman dan pemupukan kedua dilakukan setelah 2 minggu penanaman. Pupuk kompos diberikan pada setiap petak perlakuan dengan cara ditaburkan pada permukaan tanah kemudian dicampur secara merata, sedangkan biourine diberikan dengan cara diencerkan ke dalam air, kemudian disiram pada tanaman sesuai dengan dosis yang ditentukan.

\section{Pemeliharaan tanaman}

Pemeliharaan tanaman dilakukan sejak bibit rumput dan legume ditanam sampai dipanen. Adapun pemeliharaan tanaman meliputi hal-hal sebagai berikut:

\section{a. Penyiraman}

Pada awal pertumbuhan rumput gajah kate dan legume perlu mendapatkan air yang cukup. Oleh karena itu, penyiraman dilakukan setiap pagi dan sore atau tergantung cuaca dan keadaan tanah. Saat dilakukan penyiraman keadaan tanah tidak boleh terlalu basah (becek), karena dapat menyebabkan akar tanaman menjadi busuk.

b. Penyiangan

Selama pertumbuhan tanaman, dilakukan penyiangan terhadap rumput liar (gulma). Penyiangan dilakukan dengan cara mencabut rumput-rumput liar menggunakan tangan dan cangkul serta dilakukan secara hati-hati agar tidak merusak perakaran tanaman, sambil dilakukan penggemburan tanah secara hati-hati.

\section{Panen}

Dalam pemanenan tanaman rumput Gajah Kate (Pennisetum purpureum cv. Mott), Sentro (Centrocema pubescens) dan Kalopo (Calopogonium mucunoides) memerlukan waktu setelah tanaman berumur 60-70 hari atau sebelum leguminosa berbunga.

\section{Parameter yang Diamati}

1. Pertumbuhan Rumput Gajah Kate (Pennisetum purpureum cv. Mott) yang meliputi: (a) tinggi tanaman yaitu pengamatan dilakukan pada sampel rumput yang dipilih secara acak mulai dari tanaman berumur 3 minggu setelah tanam dan selanjutnya pengukuran dilakukan seminggu sekali sampai tanaman mencapai tinggi maksimum. Pengukuran tinggi tanaman mulai dari permukaan tanah sampai ujung daun yang tertinggi dengan cara meluruskan ke atas; (b) jumlah daun yaitu menghitung jumlah daun yang berwarna hijau dan telah terbuka penuh. Pengamatan dilakukan setiap satu minggu sekali sampai di dapat jumlah daun maksimum yang dimulai sejak tanaman berumur 3 minggu setelah tanam; (c) jumlah anakan yaitu menghitung anakan yang ada pada induk tanaman. Anakan yang masuk dalam perhitungan adalah anakan yang sudah menghasilkan daun yang mekar penuh.

2. KomposisiBotani

Setelah tanaman berumur 3 bulan, dilakukan pemotongan dengan tinggi $10 \mathrm{~cm}$ dari tanah, selanjutnya dilakukan penimbangan pada setiap perlakuan dan dipisahkan antara rumput, legume dan gulma untuk mengetahui komposisi botaninya.

3. Produksi Segar Total dan Produksi Berat Kering Total

Berat segar total didapatkan dengan cara menimbang produksi dari total tanaman per ha setelah dipanen. Produksi berat kering total diperoleh dengan mengalikan produksi segar total dengan kandungan bahan keringnya.

4. Kualitas Nutrisi rumput gajah kate (Pennisetum purpureum cv. Mott) meliputi:

Kandungan Protein Kasar dan Kandungan Serat Kasar Rumput Gajah Kate (Pennisetum purpureum cv. Mott).

\section{Analisa Data}

Data yang diperoleh dari hasil penelitian ini dianalisis dengan analisa sidik ragam, apabila terdapat hasil yang berbeda nyata $(\mathrm{P}<0.05)$ diantara perlakuan maka dilakukan dengan uji jarak berganda dari Duncan (Steel dan Torrie, 1989).

\section{HASIL DANPEMBAHASAN}

\section{Pertumbuhan}

Interaksi antara jenis tanaman (faktor A) dan pemupukan (faktor B) terhadap pertumbuhan rumput gajah kate (Pennisetum purpureum cv. Mott) menunjukkan pengaruh yang tidak nyata $(\mathrm{P}>0.05)$. Pertumbuhan rumput gajah kate yang ditanam bersama dengan leguminosa (faktor A) menunjukan hasil yang berbeda sangat nyata $(\mathrm{P}<0.01)$ untuk 
parameter jumlah daun dan jumlah anakan,sedangkan untuk parameter tinggi tanaman menunjukan hasil yang berbeda tidak nyata (Tabel 1). Sementara untuk faktor B (jenis pupuk) memberikan pengaruh yang tidak nyata $(\mathrm{P}>0.05)$ terhadap seluruh parameter pertumbuhan.

Tabel 1. Pengaruh Jenis Tanaman Terhadap Pertumbuhan Rumput Gajah Kate (Pennisetum purpureum Cv. Mott) Umur 10 Minggu

\begin{tabular}{lccc}
\hline \multirow{2}{*}{ Parameter } & \multicolumn{3}{c}{ Perlakuan } \\
\cline { 2 - 4 } & $\mathrm{Rt}$ & $\mathrm{Rk}$ & $\mathrm{Rs}$ \\
\hline Jumlah Daun (helai/rumpun) & $119,5^{\mathrm{a}}$ & $158,33^{\mathrm{b}}$ & $146,46^{\mathrm{b}}$ \\
Jumlah Anakan (buah) & $11,45^{\mathrm{a}}$ & $12,79^{\mathrm{b}}$ & $13,32^{\mathrm{b}}$ \\
Tinggi Tanaman (cm) & $89,33^{\mathrm{a}}$ & $89,67^{\mathrm{a}}$ & $93^{\mathrm{a}}$ \\
\hline
\end{tabular}

Keterangan: Huruf superskrip yang sama kearah baris menunjukan berbeda tidak nyata $(P>0,05)$

Tabel di atas memperlihatkan bahwa penanaman bersama dengan leguminosa mampu meningkatkan jumlah daun dan jumlah anakan rumput gajah kate, namun antara perlakuan penanaman dengan sentro dan dengan kalopo tidak menunjukkan perbedaan yang nyata. Jumlah daun yang paling banyak diperoleh pada perlakuan Rk (rumput yang ditanam bersama kalopo) yaitu sebanyak 158,33 helai/rumpun dan yang sedikit diperoleh pada perlakuan Rt yaitu sebesar 119,5 helai/rumpun. Pada perlakuan Rs (rumput ditanam bersama dengan sentro) memberikan jumlah anakan paling tinggi yaitu 13,32 buah/rumpun, sedangkan Rk 12,79 buah/rumpun namun secara statistik berbeda tidak nyata. Penanaman rumput gajah kate tanpa leguminosa (Rt) menghasilkan 11,45 buah anakan/ rumpun secara statistik berbeda nyata $(\mathrm{P}<0.05)$ dibandingkan dengan perlakuan Rs dan Rk.

Pertumbuhan tanaman ditunjukkan oleh pertambahan ukurandan berat kering, yang mencerminkan pertambahan protoplasma yang mungkin terjadi karena adanya pertambahan dan pembesaran ukuran sel. Pada penelitian ini pertumbuhan rumput gajah kate hanya dilihat dari sisi jumlah daun, jumlah anakan dan tinggi tanaman. Perlakuan jenis tanaman (faktorA) memberikan hasil yang nyata mampu meningkatkan jumlah anakan dan jumlah daun rumput gajah kate, namun tidak memberikan pengaruh yang nyata terhadap tinggi tanaman.Rata-rata tinggi rumput gajah kate pada penelitian ini 90,67 cm. Hal ini sesuai dengan pendapat Syarifuddin (2006) bahwa tinggi tanaman rumput gajah kate dapat mencapai 1 meter. Peningkatan jumlah anakan akan diikuti dengan peningkatan jumlah daun, dan selanjutnya akan diikuti dengan peningkatan produksi segarnya. Rumput gajah kate merupakan salah satu jenis hijauan pakan ternak yang tumbuh merumpun dengan perakaran serabut yang kompak dan akan terus menghasilkan anakan apabila dipangkas secara teratur. Lebar rumpun bisa mencapai 1 meter (Anonim, 2005).

\section{Produksi Segar Total dan Bahan Kering Total}

Panen pertama dilakukan setelah tanaman berumur 12 minggu dengan cara memotong $10 \mathrm{~cm}$ di atas permukaan tanah. Jenis tanaman (faktorA) nyata meningkat produksi segar total hijauan, sedangankan jenis pupuk (faktor B ) menunjukkan hasil yang tidak nyata dan tidak terdapat interaksi antara keduanya. Produksi segar total tertinggi diperoleh pada perlakuan Rs yaitu sebesar 99,28 ton/ ha dan menurun pada perlakuan Rk yaitu sebesar 97,7 ton/ha. Pada perlakuan Rt produksi segar total sebesar 46,35 ton/ha dan berbeda secara sangat nyata $(\mathrm{P}<0.01)$. Hal yang sama juga terjadi pada produksi berat kering total hijauan dimana pada perlakuan Rs memberikan hasil yang paling tinggi sebesar 26,11ton/ ha diikuti dengan Rk sebesar 25,90 ton/ha dan yang paling kecil adalah Rt sebesar13,04 ton/ha.

Produksi segar total hijauan paling tinggi diperoleh pada kombinasi pertanaman campuran rumput gajah kate dengan sentro diikuti dengan pertanaman rumput gajah kate dengan kalopo dan produksi terendah didapatkan pada pertanaman tunggal. Peranan leguminosa dalam sistem asosiasi adalah untuk member tambahan nitrogen pada rumput dan memperbaiki kandungan hara secara menyeluruh pada padang penggembalaan terutama protein, fosfor dan kalium. Sementara itu leguminosa yang berbeda mempunyai kemampuan untuk berkompetisi secara berbeda, dan sangat ditentukan oleh sistem perakaran, lebar daun,dan sifat morfologis lainnya. Kebanyakan leguminosa kebutuhan nitrogennya bergantung kepada $\mathrm{N}$ hasil fiksasi bukan dari $\mathrm{N}$ anorganik. Hal ini tentunya akan sangat mempengaruhi pertumbuhan leguminosa itu sendiri, sehingga $\mathrm{N}$ anorganik yang terdapat dalam tanah dapat dimanfaatkan oleh tanaman lainnya (Sanchez, 1993). Hal inilah yang mendorong lebih tingginya produksi pastura campuran.

Tabel 2. Pengaruh Jenis Tanaman Terhadap Produksi Segar Total dan Produksi Bahan Kering Total Rumput Gajah Kate (Pennisetum uprpureum $\mathrm{Cv}$. Mott) (Ton/ha)

\begin{tabular}{lccc}
\hline \multirow{2}{*}{ Parameter } & \multicolumn{3}{c}{ Perlakuan } \\
\cline { 2 - 4 } & Rt & Rk & Rs \\
\hline Produksi Segar Total & $46,35^{\mathrm{b}}$ & $99,28^{\mathrm{a}}$ & $97,70^{\mathrm{a}}$ \\
Produksi Bahan Kering Total & $13,04^{\mathrm{b}}$ & $26,11^{\mathrm{a}}$ & $25,90^{\mathrm{a}}$ \\
\hline
\end{tabular}

Keterangan : Huruf superskrip yang sama kearah baris menunjukan berbeda tidak nyata $(P>0,05)$.

\section{Komposisi Botani}

Pertanaman campuran rumput dengan leguminosa (faktor A) secara nyata dapat menurunkan prosentase komposisi rumput di dalam komposisi botani dan 
secara statistik berbeda nyata $(\mathrm{P}<0.05)$, sedangkan jenis pupuk (faktor B) memberikan hasil yang tidak nyata ( $>>0.05$ ) (tabel 3). Komposisi botani pada perlakuan Rk berbeda sangat nyata dengan perlakuan Rs dan Rt. Jenis leguminosa sentro mampu menekan pertumbuhan rumput menjadi paling rendah dan antara kalopo dengan sentro menunjukkan hasil yang berbeda sangat nyata $(\mathrm{P}<0.01)$. Untuk komposisi botani leguminosa prosentase leguminosa paling tinggi ada pada tanaman sentro dan secara statistic berbeda nyata $(\mathrm{P}<0,05)$, sementara itu untuk komposisi gulma antara jenis tanaman menunjukkan hasil yang berbeda tidak nyata $(\mathrm{P}>0.05)$.

Tabel 3. Pengaruh Jenis Tanaman Terhadap Komposisi Botani Rumput Gajah Kate (Pennisetum Purpureum cv. Mott)

\begin{tabular}{lccc}
\hline \multirow{2}{*}{\multicolumn{1}{c}{ Parameter }} & \multicolumn{3}{c}{ Perlakuan } \\
\cline { 2 - 4 } & $\mathrm{Rt}$ & $\mathrm{Rk}$ & $\mathrm{Rs}$ \\
\hline Prosentase Rumput & $99,54^{\mathrm{a}}$ & $64,86^{\mathrm{c}}$ & $76,28^{\mathrm{b}}$ \\
Prosentase Leguminosa & - & $34,8^{\mathrm{a}}$ & $23,27^{\mathrm{b}}$ \\
Prosentase Gulma & $0,46^{\mathrm{a}}$ & $0,35^{\mathrm{a}}$ & $0,46^{\mathrm{a}}$
\end{tabular}

Keterangan : Huruf superskrip yang sama kearah baris menunjukan berbeda tidak nyata $(P>0,05)$.

Perlakuan jenis tanaman (faktor A) memberikan pengaruh yang nyata terhadap komposisi botani. Pertanaman campuran rumput gajah kate dengan leguminosa secara nyata mampu menekan komposisi rumput dan meningkatkan jumlah komposisi leguminosanya. Komposisi gulma yang tumbuh tidak memperlihatkan pengaruh dari kedua perlakuan. Asosiasi antara rumput dengan legume sampai dengan imbangan rumput: legume $=70 \%: 30 \%$ merupakan komposisi yang paling diharapkan, mengingat komposisi pakan yang ideal adalah 70\% rumput dan $30 \%$ legum. Komposisi ini sudah dicapai mengingat kemampuan legume untuk tumbuh kembali setelah defoliasi sangatlah berkompetisi dengan rumput yang mempunyai sistem perakaan yang lebih bagus (Whiteman, 1980).

Kompetisi antar spesies tanaman yang berbeda atau pada spesies yang sama meliputi banyak faktor. Penampilan spesies tanaman yang berbeda dalam asosiasi akan berbeda dan sangat depresif sehingga tidak menunjukkan interaksi yang menguntungkan. Kompetisi ini akan selalu muncul jika dua tanaman atau lebih membutuhkan cahaya, nutrient atau air melebihi ketersediaan. Kompetisi akhirnya mengurangi jumlah faktor yang essensial bagi masingmasing individu. Komponen yang lebih kompetitif dalam suatu asosiasi biasanya tumbuh lebih cepat, lebih cepat menyebar dan menghasilkan hijauan yang lebih banyak.

\section{Kualitas Nutrisi}

Kualitas Nutrisi yang diamati adalah kandungan protein kasar baik itu hasil dari pertanaman tunggal maupun campuran. Dari hasil penelitian diperoleh bahwa jenis tanaman (faktor A) menunjukkan pengaruh yang nyata terhadap kandungan protein kasar rumput gajah kate, sedangkan jenis pupuk (faktor B )menunjukkan pengaruh yang tidak nyata $(\mathrm{P}<0.05)$ dan tidak terdapat interaksi diantara keduanya. Kandungan protein kasar hijauan yang ditanam bersama dengan leguminosa (Rs dan Rk) lebih tinggi 10,40\% dan 12,87\% dibandingkan dengan Rt dan secara statistik berbeda nyata $(\mathrm{P}<0.05)$, Perlakuan Rk memberikan hasil yang lebih tinggi 2,24\% dibandingkan Rs namun secara statistik tidak berbeda nyata $(\mathrm{P}<0.05)($ Tabel4).

Tabel 4. Pengaruh Jenis Tanaman Terhadap Kualitas Nutrisi Rumput Gajah Kate (Pennisetum Purpureum cv. Mott)

\begin{tabular}{lccc}
\hline \multirow{2}{*}{ Parameter } & \multicolumn{3}{c}{ Perlakuan } \\
\cline { 2 - 4 } & $\mathrm{Rt}$ & $\mathrm{Rk}$ & $\mathrm{Rs}$ \\
\hline Protein Kasar (\%) & $8,08^{\mathrm{b}}$ & $8,92^{\mathrm{a}}$ & $9,12^{\mathrm{a}}$ \\
Serat Kasar (\%) & $32,02^{\mathrm{a}}$ & $32,33^{\mathrm{a}}$ & $32,70^{\mathrm{a}}$ \\
\hline
\end{tabular}

Keterangan : Huruf superskrip yang sama kearah baris menunjukan berbeda tidak nyata $(P>0,05)$.

Ada beberapa faktor yang mempengaruhi komposisi hijauan yaitu (1) pengaruh tanah, yaitu dibutuhkan kesuburan fisik, kimia dan biologis tanah; (2) pengaruh tanaman meliputi jenis tanaman, umur tanaman dan bagian tanaman, (3) Pengaruh iklim meliputi temperatur, curah hujan dan kelembaban (Djuned,dkk. 1980). Kualitas nutrisi rumput gajah kate meningkat seiring dengan pertanaman campuran rumput dan leguminosa. Jenis tanaman (faktor A) secara nyata meningkatkan kandungan Protein Kasar rumput gajah kate. Penanaman tunggal rumput gajah kate (Rt) menghasilkan kandungan protein kasar yang paling rendah yaitu sebesar $8.08 \%$. Penanaman campuran baik dengan sentro maupun dengan kalopo dapat meningkatkan kandungan protein rumput gajah kate yaitu 8,92 \% untukRs dan 9,12 \% untuk Rk. Pada asosiasi tanaman rumput dengan legum, legum akan mensuplai $\mathrm{N}$ kepada rumput dalam bentuk bintil- bintil (nodule) akar yang telah terlepas dari inangnya yang akan dimanfaatkan oleh rumput sehingga pertumbuhan dan produksi rumput dapat meningkat (Miller,1984). Hal yang berbeda disampaikan oleh Bogdan (1977), dimana dikatakan bahwa selama petumbuhan tanaman yang berasosiasi, $\mathrm{N}$ yang dipergunakan oleh legum terutama digunakan oleh legum itu sendiri, dan yang ditransfer ke rumput dalam jumlah yang sangat terbatas. Transfer $\mathrm{N}$ pada legum tidak berkorelasi dengan banyaknya $\mathrm{N}$ yang difiksasi oleh legum. Dalam simbiose rhizobiumlegum, legum menyediakan karbohidrat yang dapat 
dimanfaatkan oleh rhizobium sebagai sumber energi, sebaliknya rhizobium menyediakan $\mathrm{N}$ yang dapat dimanfaatkan oleh legum untuk mensintesa asamasam amino dan protein tanaman (Skerman, 1977).

McIllroy (1977) menyatakan bahwa dalam memanfaatkan lahan secara efisien dapat dilakukan dengan penanaman campuran legum dengan rumputrumputan. Pertanaman campuran akan sangat menguntungkan karena legume dapat menyediakan $\mathrm{N}$ bagi rumput, sehingga produksi bias lebih baik dan menghemat pemupukan. Selanjutnya dikatakan bahwa nilaigizi jenis hijauan makanan ternak dipengaruhi oleh perbandingan daun/batang, fase pertumbuhan, kesuburan tanah dan pemupukan, serta keadaan iklim. Legum pada umumnya lebih kaya akan N, Pdan K dibandingkan dengan rumput (Bogdan,1977).

Nodulasi legume juga dapat mempertahankan tingginya konsentrasi protein pada rumput, sehingga keberadaan legum dalam hijauan akan memberikan pakan yang lebih baik bagi ternak (Skerman, 1977). Meskipun rumput mempunyai kemampuan untuk menghasilkan produksi yang tinggi, tetapi kandungan proteinnya relatif lebih rendah dibandingkan dengan legum. Menurut Sanchez (1993), peranan legum dalam sistem asosiasi rumput legume adalah untuk memberikan tambahan nitrogen kepada rumput dan memperbaiki kandungan hara secara menyeluruh pada padang penggembalaan terutama protein, fosfor dan kalium. Rumput diharapkan dapa tmenyediakan sejumlah energi yang besar bagi ternak ruminansia karena produksi bahan keringnya yang lebih banyak. Selain daripada itu, sistem penanaman campuran akan didapatkan pakan yang berkualitas karena komposisi pakan ruminansia yang baik adalah jika tersusun dari rumput dan legum (Dubbs,1971). Penanaman campuran rumput dan leguminosa juga akan memberikan produksi hijauan yang tidak berfluktuasi pada tiap-tiap musimnya (Miller,1984). McIllroy (1977) menyatakan bahwa keuntungan legum bila dibandingkan dengan rumput adalah bahwa legume mempunyai kemampuan untuk mengikat nitrogen atmosfer dalam simbiosenya dengan bakteri rhizobia.

Rumput dan legum adalah tanaman pakan yang mempunyai lintasan fotosintesis yang berbeda. Rumput tropis kebanyakan memiliki lintasan fotosistesis $\mathrm{C}_{4}$, sedangkan legum mempunyai lintasan fotosintesis $\mathrm{C}_{3}$. Fiksasi $\mathrm{CO}_{2}$ pada tanaman $\mathrm{C}_{3}$ dan $\mathrm{C}_{4}$ ini dapat dipengaruhi secara langsung. Daun-daun tanaman dengan fiksasi $\mathrm{C}_{3}$ akan menjadi cepat jenuh pada intensitas cahaya yang relative lebih rendah jika dibandingkan dengan jenis yang mempunyai lintasan C4, oleh karena itu $\mathrm{C}_{3}$ akan lebih sesuai tumbuh pada habitat yang ternaungi. Sebaliknya $\mathrm{C}_{4}$ akan lebih efisien dalam menggunakan air sehingga lebih kompetitif dibandingkan dengan tanaman lainnya
(Sastroutomo,1990). Dilihat dari pola fiksasi ini, nampaknya antara rumput dan legume sangat cocok diusahakan dalam bentuk asosiasi tanaman.

Asosiasi tanaman rumput-legum pada pasture campuran tidak memerlukan pemberian nitrogen apabila komposisi legume melebihi dari 30\% dari pertanaman campuran tersebut, tetapi perlu diusahakan pemupukan $\mathrm{P}$ dan K (Miller, 1984). Kebutuhan $\mathrm{N}$ akan dipenuhi oleh legume untuk pertumbuhan rumput sebagai komponen pasture campuran. Setelah terjadi penurunan komponen legum sampai dibawah 30\%, maka perlu dilakukan pemupukan dengan tujuan untuk meningkatkan hasil rumput. Lebih lanjut, Djuned, dkk. (1980) menyatakan bahwa ada beberapa faktor yang mempengaruhi komposisi kimia hijauan diantaranya adalah faktor tanaman meliputi umur, jenis dan bagian tanaman. Daun mempunyai nilai protein yang lebih tinggi dibandingkan dengan batang, karena pada batang lebih banyak mengandung serat kasar dibandingkan dengan daun.

\section{KESIMPULAN}

Berdasarkan hasil dan pembahasan ini dapat disimpulkan sebagaiberikut:

1. Tidak terdapat interaksi antara jenis tanaman dengan jenis pupuk terhadap pertumbuhan, produksi dan komposisi botani serta kualitas nutrisi rumput Gajah Kate (Pennisetum purpureum cv. Mott)

2. Jenis tanaman memberikan pengaruh yang nyata terhadap parameter pertumbuhan khususnya jumlah anakan dan jumlah daun, produksi total hijuan baik segar maupun kering, komposisi botani (prosentase rumput dan leguminosa) dan kualitas nutrisi (protein kasar) hijauan rumput Gajah Kate (Pennisetum purpureum cv. Mott), tetapi tidak memberikan pengaruh yang nyata pada tinggi tanaman, kandungan serat kasar dan prosentase gulma.

3. Jenis pupuk tidak memberikan pengaruh yang nyata terhadap pertumbuhan, produksi dan komposisi botani serta kualitas nutrisi rumput Gajah Kate (Pennisetum purpureum cv. Mott).

\section{REFERENSI}

Anonim. 1999. Petunjuk Teknis Budidaya Pakan Hijauan. Jakarta: Direktorat Bina Produksi dan JICA.

Anonim, 2005. Rumput Gajah. Http://www.hear. org/pier/spescies/pennicetumpurpureum.html. Diakses tanggal 1 Maret 2016.

Bogdan, A.V. 1977. Tropical Pasture and Fodder for 
small holder Livestock Production in The Tropics. Longman London and New York.

Chullank, 2012. Makalah Hasil Penelitian Kompatibilitas Rumput Gajah Mini (Pennisetum purpureum cv. Mott) dengan Kacang Pinto (Arachis Pintoi) Pada Berbagai Proporsi. http://chullank.blogspot. co.id. Diakses tanggal o1 Maret 2016.

Crowder, L.V.dan H.R.Cheda. 1982. Tropical Grassland Husbandry. Longman, London and New York.

Djuned H, M.H.D Wiradisastra, T.Y. Aisyah dan Ana Rohana. 1980. Tanaman Makanan Ternak. Bagian Makanan Ternak. Fakultas Peternakan. Universitas Padjdjaran Bandung.

Dubbs, A.I. 1971. Competition Between Grassand Legumes Spesieson Dryland. Agron.J.63:359-362

Humphreys. L.R. 1974. Guide T Better Pastures For The Tropics \& Sub Tropic. Wright. Stephenson anmd Co, England.

Ibrahim, 1995. Daya Adaptasi Rumput dan Legum Asal Ciat (Colombia) dan CSIRO (Australia) Di Kalimantan Timur. Dalam Proseding Seminar Nasional Sains dan Teknologi Peternakan 1995. Pusat Penelitian dan Pengembangan Peternakan. Badan Penelitian dan Pengembangan Pertanian.

McIlroy, R.J. 1977. Pengantar Budidaya Padang Rumput Tropika. Diterjemahkan oleh Subadio Susetyo dkk. Pradnya Paramita,Jakarta.
Miller,D.A. 1984. Forages Crops. McGraw-Hill Book Company, New York.

Reksohadiprodjo Soedomo. 1994. Produksi Tanaman Hijauan Makanan Ternak Tropik. B.P.F.E. University Gadjah Mada,Yogyakarta.

Rica,M.S. 2012. Produksi dan Nilai Nutrisi Rumput Gajah (Pennisetum Purpureum cv. Mott) yang diberi dosis pupuk N,P,K berbeda pada lahan kritis tambang batubara. Artikel, ProgramStudi Ilmu Peternakan Pascasarjana Universitas Andalas Padang.

Sanchez. P.A. 1993. Sifat dan Pengelolaan Tanah Tropika. Jilid 2. Terjemahan Amir Hamzah. Penerbit Institut Teknologi Bandung. Bandung

Sastrautomo, S. 1990. Ekologi Gulma. Gramedia Pustaka Utama. Jakarta

Skerman, P.J. 1977. Tropical Farage Legumes. Food and Agriculture Organization of The United Nations. Rome.

Sumarsono, 2005. Peranan Pupuk Organik Untuk Perbaikan Penampilan dan Produksi Hijauan Rumput Gajah Pada Tanah Cekaman Salinitas dan Kemasaman, Fakultas Peternakan Universitas Diponegoro, Semarang.

Whiteman, P.C. 1980. Tropical Pasture Science.Oxford University Press. Oxford. 